\title{
ANALISIS FASILITAS PARKIR DAN AKSESIBILITAS OBJEK WISATA GOA GONG, PACITAN
}

\author{
Sulistiani ${ }^{1}$ dan Ahmad Munawar ${ }^{2}$ \\ ${ }^{1}$ Magister Sistem dan Teknik Transportasi, Fakultas Teknik, Universitas Gadjah Mada, \\ sulismadiyo@gmail.com \\ ${ }^{2}$ Magister Sistem dan Teknik Transportasi, Fakultas Teknik, Universitas Gadjah Mada, \\ munawar@ugm.ac.id \\ Jl. Grafika No. 2 Kampus UGM, Yogyakarta 55281.
}

\begin{abstract}
ABSTRAK
Kabupaten Pacitan dikenal dengan "Kota 1001 Goa" dan salah satu ikonnya adalah Goa Gong. Kemudahan mencapai objek wisata serta ketersediaan fasilitas parkir yang memadai merupakan salah satu faktor yang menentukan tingkat kunjungan wisatawan. Tingginya volume kendaraan pada akses jalan utama menuju Goa Gong terjadi karena akses tersebut juga merupakan akses utama ke objek wisata lainnya. Penurunan tingkat pelayanan jalan diperparah dengan banyaknya kendaraan yang parkir di badan jalan karena kapasitas ruang parkir yang tersedia tidak mencukupi.Penelitian ini bertujuan untuk mengevaluasi fasilitas parkir di Objek Wisata Goa Gong, mengevaluasi aksesibilitas di Objek Wisata Goa Gong dan memberikan alternatif penanganan masalah fasilitas parkir dan aksesibilitas untuk pengembangan Objek Wisata Goa Gong. Perhitungan parkir dilakukan pada off-street parking. Evaluasi aksesibilitas menggunakan analisis tingkat pelayanan jalan mengacu pada formulasi MKJI 1997 Jalan Luar Kota. Tingkat pelayanan jalan didasarkan pada Derajat Kejenuhan. Berdasarkan hasil penelitian terdapat permasalahan fasilitas parkir dengan masih banyaknya parkir di badan jalan dan nilai indeks parkir mencapai lebih dari 70\% pada jam-jam tertentu. Aksesibilitas di Objek Wisata Goa belum mengalami masalah yang berarti dimana tingkat kinerja jalan masih dalam kategori A. Berdasarkan hasil prediksi, maka tingkat pelayanan jalan di akses utama Goa Gong dalam waktu 5 tahun mendatang (Tahun 2022) menjadi kategori B pada hari Sabtu dan kategori C pada hari Minggu. Jika hal ini tidak segera ditangani maka akan menyebabkan permasalahan yang lebih serius. Prioritas penanganan yaitu dengan penambahan kapasitas ruang parkir dan manajemen parkir, sedangkan alternatif pemecahan masalah lainnya yaitu dengan pelebaran jalan dan penyediaan angkutan umum wisata.
\end{abstract}

Kata kunci : Kebutuhan Parkir, Derajat Kejenuhan, Kecepatan, Alternatif Penanganan, Goa Gong

\section{PENDAHULUAN}

Kabupaten Pacitan mempunyai potensi pariwisata yang dapat dikembangkan lebih baik lagi dengan didukung banyaknya objek wisata alam yang indah dengan didominasi objek wisata pantai dan gua yang tersebar di seluruh wilayah Kabupaten Pacitan. Pengembangan dan perluasan pariwisata harus didukung oleh semua pihak untuk baik pemerintah, swasta maupun masyarakat, dan oleh sektor-sektor yang lain, terutama sektor transportasi sebagai infrastruktur pendukung utama objek wisata.

Sektor pariwisata merupakan salah satu pendorong pertumbuhan ekonomi di Kabupaten Pacitan. Untuk dapat terus meningkatkan Pendapatan Asli Daerah dari sektor pariwisata, maka perlu didukung oleh sarana dan prasarana yang memadai, baik fasilitas parkir, jalan, maupun fasilitas pendukung lainnya. Faktor aksesibilitas merupakan salah satu unsur pokok dan mendasar dalam pengembangan kepariwisataan yang mempengaruhi mobilitas wisatawan. Kemudahan mencapai objek wisata serta ketersediaan fasilitas parkir yang memadai merupakan faktor penting dalam meningkat kunjungan wisatawan.

Kabupaten Pacitan dikenal dengan "Kota 1001 Goa" dan salah satu ikonnya adalah Goa Gong. Goa Gong termasuk dalam kawasan bentang alam karst, Global Geopark Network (GGN) UNESCO, Kawasan Strategis Pariwisata Nasional (KSPN) dan Kawasan Pengembangan Pariwisata Nasional (KPPN). Jumlah wisatawan yang terus meningkat berpengaruh terhadap kondisi fasilitas parkir dan aksesibilitas di Objek Wisata Goa Gong.

Permasalahan transportasi sering terjadi pada akhir pekan dan hari-hari libur di sekitar Objek Wisata Goa Gong. Permasalahan tersebut antara lain banyaknya parkir di badan jalan karena kapasitas pelataran parkir yang tidak mencukupi dan adanya tundaan di sekitar Objek Wisata Goa Gong. Ruang parkir di area Goa Gong merupakan area parkir untuk wisatawan Goa Gong dan objek wisata lainnya, dimana untuk wisatawan yang melakukan perjalanan dengan menggunakan bus berganti moda angkutan umum. Kendaraan yang parkir di badan jalan 
selain kendaraan wisatawan karena terbatasnya ruang parkir juga kendaraan angkutan umum yang menunggu penumpang menuju objek wisata lainnya.

Tingginya volume kendaraan pada akses jalan utama menuju Goa Gong juga terjadi karena akses tersebut merupakan akses utama untuk objek wisata lainnya di sebelah barat Kota Pacitan, sehingga mempengaruhi tingkat pelayanan jalan. Akses jalan yang lain masih sangat terbatas, dengan lebar jalan yang hanya sekitar 3,5 $\mathrm{m}$ dengan kondisi perkerasan yang sudah mengalami kerusakan. Ruas jalan alternatif juga memiliki gradien yang besar dan belokan yang tajam sehingga hanya dapat dilalui oleh kendaraan penumpang, sedangkan bus akan kesulitan untuk dapat mengakses jalan tersebut. Kondisi ini menyebabkan tingginya volume kendaraan di ruas jalan akses utama menuju Objek Wisata Goa Gong.

Penelitian ini bertujuan untuk mengevaluasi fasilitas parkir di Objek Wisata Goa Gong, mengevaluasi aksesibilitas di Objek Wisata Goa Gong dan memberikan alternatif penanganan masalah fasilitas parkir dan aksesibilitas untuk pengembangan Objek Wisata Goa Gong.

Permasalahan area parkir merupakan suatu fenomena yang patut untuk ditelaah. Adanya evaluasi ini diharapkan memberikan suatu alternatif pemecahan masalah terhadap permasalahan kebutuhan lahan parkir, dimana luas lahan parkir yang tersedia tidak mencukupi untuk menampung jumlah kendaraan yang parkir. Fasilitas dan luasan parkir yang kurang memadai menjadi kendala utama yang dialami sehingga perlu penambahan luas area parkir (Nabal, 2014).

Tempat parkir merupakan salah satu bagian dari sekian banyak prasarana transportasi. Keterbatasan penyediaan prasarana transportasi khususnya tempat parkir, memaksa badan jalan dijadikan sebagai tempat parkir, sehingga terjadi kemacetan lalu lintas. Kemacetan lalu lintas berawal dari hambatan, delay, stagnasi yang terjadi pada lajur lalu lintas (Supriatna, 2008).

Kurangnya lahan parkir di objek wisata menyebabkan banyak pengunjung yang memilih untuk memakirkan kendaraannya di badan jalan. Selain itu pengunjung merasa relatif dekat dengan jalan sebagai media penghubung antara satu tempat dengan tempat lain, suatu kepentingan dengan kepentingan lain, akibatnya terjadinya kemacetan di sekitar objek wisata tersebut (Savenny, 2017).

Ruang parkir yang belum mencukupi untuk menampung kendaraan wisatawan yang parkir perlu ditentukan berapa besar kebutuhan ruang parkir di kawasan objek wisata serta perlu adanya penataan parkir karena pada jam tertentu perparkiran di kawasan objek wisata sangat padat (Rahmawati, 2016).

Aktivitas sisi jalan yang tinggi dapat menimbulkan gangguan terhadap pergerakan arus lalu lintas. Konflik yang terjadi seperti tundaan mempunyai potensi menyebabkan terjadinya kemacetan. Kemacetan dapat menurunkan tingkat keamanan dan kenyamanan bagi pengguna jalan, menurunkan kecepatan perjalanan, menambah waktu perjalanan dan naiknya biaya operasi kendaraan. Semakin tinggi aktivitas sisi jalan, kapasitas jalan makin rendah dan nilai derajat kejenuhan tinggi (Asih dan Muthohar, 2012).

Aksesibilitas merupakan faktor penting dalam mendukung kegiatan wisata, karena dengan kemudahan aksesibilitas membuat jarak semakin pendek dan waktu tempuh lebih efisien. Kualitas transportasi dalam kepariwisataan sangat penting, tetapi perlu diperhatikan juga kemudahan untuk mendapatkan transportasi tersebut, serta harga yang kompetitif serta tetap memperhatikan keselamatan para wisatawan (Moeis dan Fahmi, 2012).

Fasilitas transportasi yang tersedia dengan cukup, aman, terjangkau menuju objek wisata akan dapat memicu peningkatan jumlah wisatawan yang akan berkunjung dan pengembangan objek wisata akan dapat merangsang pengembangan transportasi. Aksesibilitas merupakan fungsi utama dasar angkutan pariwisata. Untuk mengakses lokasi yang merupakan tujuan utama, maka wisatawan akan menggunakan moda transportasi. Hubungan antara pariwisata dan transportasi terutama sangat dipengaruhi oleh dua elemen yaitu kemudahan mengakses tujuan (convenient access), dan kualitas layanan transportasi harus memenuhi harapan pengguna seperti tingkat keamanan, kenyamanan, frekuensi, efisiensi dan keandalan (Tambunan, 2009).

Menurut Ningsih (2010), tingkat pelayanan jalan merupakan suatu metode yang mungkin untuk memberikan ukuran untuk kondisi suatu ruas jalan yang ada saat ini masih memenuhi syarat untuk dilalui oleh volume maksimum lalu lintas/pemakai jalan yang ada saat ini dan peningkatannya hingga masa yang akan datang. Analisa kepadatan lalu lintas dibutuhkan untuk mengetahui kepadatan lalu lintas pada suatu jalan sehingga dapat diketahui kepadatan lalu lintas di jalur utama jaringan jalan. Analisa dilakukan untuk mengetahui apakah 
kondisi suatu ruas jalan yang ada saat ini masih memenuhi syarat untuk dilalui oleh volume maksimum lalu lintas/pemakai jalan dengan cara mengetahui tingkat pelayanan jalan (LOS/Level Of Service).

Menurut Ciptaningrum, dkk (2016), klasifikasi tingkat kemacetan jalan raya sebagai refleksi kinerja jalan raya. Parameter yang digunakan adalah kecepatan tempuh dan waktu tunda, dikarenakan kedua parameter tersebut mendukung data arus lalu lintas di ruas jalan. Salah satu parameter yang dapat digunakan dalam pengukuran kinerja jalan raya adalah kecepatan karena datanya bersifat stabil, dapat diulang, berpengaruh besar terhadap kemacetan (refleksi langsung), dan nilainya bersifat kontinyu. Salah satu metode yang dapat digunakan untuk mengukur kecepatan kendaraan yang efisien dan secara real time menggunakan metode floating car data (FCD)

\section{LANDASAN TEORI}

\subsection{Parkir}

Perhitungan data parkir dapat dilakukan dengan persamaan sebagai berikut (Munawar, 2004)

\subsubsection{Akumulasi Parkir}

Akumulasi Parkir : Jumlah kendaraan yang di parkir di suatu tempat pada waktu tertentu. Perhitungan akumulasi parkir dapat menggunakan persamaan (1).

Akumulasi $=\mathrm{Ei}-\mathrm{Ex}$

Dengan, Ei = Entry / kendaraan yang masuk lokasi (kendaraan). $\mathrm{Ex}=$ Exit $/$ kendaraan yang keluar lokasi (kendaraan).

Jika sudah sudah ada kendaraan parkir sebelum pengamatan maka banyaknya kendaraan yang telah parkir dijumlahkan dalam akumulasi parkir yang telah dibuat, sehingga persamaan di atas menjadi persamaan (2).

Akumulasi $=\mathrm{Ei}-\mathrm{Ex}+\mathrm{X}$

\subsubsection{Durasi Parkir}

Durasi parkir : rentang waktu sebuah kendaraan parkir di suatu tempat (dalam satuan menit atau jam). Nilai durasi parkir diperoleh dengan persamaan (3).

Durasi $=$ Extime - Entime

Dengan, Extime = waktu saat kendaraan keluar dari lokasi parkir.

Entime $=$ waktu saat kendaraan masuk ke lokasi parkir.

\subsubsection{Turnover parkir :}

Turnover parkir : tingkat penggunaan ruang parkir. Turnover diperoleh dengan membagi volume parkir dengan jumlah ruang-ruang parkir untuk suatu periode tertentu, melalui persamaan (4).

Tingkat Turnover $=\frac{\text { Volume Parkir }}{\text { Ruang Parkir yang tersedia }}$

\subsubsection{Indeks Parkir :}

Indeks parkir : ukuran untuk menyatakan penggunaan jalan dan dinyatakan dalam presentasi ruang yang ditempati oleh kendaraan parkir. Besarnya indeks parkir diperoleh dengan persamaan (5).

Indeks Parkir $=\frac{\text { Akumulasi Parkir } \mathrm{x} 100 \%}{\text { Ruang Parkir yang tersedia }}$

\subsubsection{Rata-rata durasi parkir}

Rata-rata durasi parkir merupakan rata-rata durasi parkir dari semua kendaraan yang parkir. Rata-rata durtasi parkir diperoleh dengan menjumlahkan semua durasi parkir kendaraan dibagi dengan jumlah kendaraan yang parkir. Besarnya rata-rata durasi parkir diperoleh dengan persamaan (6). 
$D=\frac{\sum_{n}^{i=n} \mathrm{di}}{\mathrm{n}}$

Dengan :

$\mathrm{D}=$ rata-rata durasi parkir kendaraan

di $=$ durasi kendaraan ke-i (i dari kendaraan ke-i hingga ke-n)

\subsubsection{Jumlah ruang parkir yang dibutuhkan}

Jumlah ruang parkir yang dibutuhkan merupakan jumlah kebutuhan ruang parkir yang terjadi selama waktu pengamatan. Jumlah ruang parkir yang dibutuhkan diperoleh dengan mengalikan jumlah kendaraan parkir selama waktu pengamatan dengan rata-rata durasi parkir yang kemudian dibagi dengan lamanya waktu pengamatan. Besarnya jumlah ruang parkir yang dibutuhkan diperoleh dengan persamaan (7).

$Z=\frac{Y \cdot D}{T}$

Dengan :

$Z=$ Ruang parkir yang dibutuhkan (unit).

$\mathrm{Y}=$ Jumlah kendaraan parkir dalam satu waktu (unit).

$\mathrm{D}=$ Rata-rata durasi parkir (jam).

$\mathrm{T}=$ Lama survei $(\mathrm{jam})$.

\subsection{Aksesibilitas}

\subsubsection{Data Fisik Jalan}

Data Fisik jalan merupakan salah satu karakteristik utama jalan yang akan mempengaruhi kapasitas dan tingkat pelayanan jalan dengan memperhatikan beban lalu lintas.

\subsubsection{Hambatan Samping}

Aktivitas samping jalan yang dapat menimbulkan konflik dan berpengaruh terhadap pergerakan arus lalu lintas serta menurunkan fungsi kinerja jalan. Tingkat hambatan samping dikelompokkan dalam lima kelas yaitu sangat rendah, rendah, sedang, tinggi dan sangat tinggi (MKJI, 1997).

\subsubsection{Volume (Q)}

Volume adalah jumlah kendaraan yang melewati titik pengamatan dalam periode waktu tertentu. Nilai volume lalu lintas dinyatakan dalam satuan mobil penumpang (smp) yang dikonversikan dengan mengalikan nilai ekivalensi mobil penumpang (emp). Volume lalu lintas diperoleh dengan membandingkan jumlah kendaraan dengan waktu, sebagaimana persamaan (8).

$\mathrm{Q}=\mathrm{N} / \mathrm{T}$

Dengan :

$\mathrm{V}=$ Volume $(\mathrm{kend} / \mathrm{jam})$.

$\mathrm{N}=$ Jumlah Kendaraan (kend).

$\mathrm{T}=$ Waktu Pengamatan (jam).

\subsubsection{Kapasitas Jalan}

Kapasitas dinyatakan dalam satuan mobil penumpang (smp), Persamaan dasar untuk penentuan kapasitas mengikuti persamaan (9).

C $=$ Co $\times$ FCw $\times$ FCsp $\times$ FCsf

Dengan :

$\mathrm{C} \quad=$ kapasitas $(\mathrm{smp} / \mathrm{jam})$.

$\mathrm{C}_{\mathrm{O}} \quad=$ kapasitas dasar (smp/jam) .

$\mathrm{FCw}=$ faktor penyesuaian lebar jalan.

$\mathrm{FCsp}=$ faktor penyesuaian pemisahan arah. 
FCsf = faktor penyesuaian hambatan samping.

\subsubsection{Derajat Kejenuhan}

Nilai Derajat kejenuhan menunjukkan apakah segmen jalan akan mempunyai masalah kapasitas atau tidak. Derajat Kejenuhan diperoleh dengan persamaan (10).

$\mathrm{DS}=\mathrm{Q} / \mathrm{C}$

Dengan :

$\mathrm{DS}=$ Derajat Kejenuhan

$\mathrm{Q}=$ Arus total.

$\mathrm{C}=$ Kapasitas.

\subsubsection{Kecepatan}

Kecepatan dalam penelitian ini menggunakan kecepatan tempuh sebagai mana yang digunakan dalam MKJI (1997), sebagai salah satu ukuran dalam penentuan tingkat pelayanan jalan. Adapun persamaan untuk menentukan kecepatan adalah persamaan (11).

$\mathrm{V}=\mathrm{L} / \mathrm{TT}$

Dengan :

$\mathrm{V}=$ Kecepatan ruang rata-rata kendaraan ringan $(\mathrm{km} / \mathrm{jam})$.

$\mathrm{L} \quad=$ Panjang segmen $(\mathrm{km})$.

$\mathrm{TT}=$ Waktu tempuh rata-rata kendaraan ringan sepanjang segmen (jam).

\section{METODOLOGI}

Pada penelitian ini, terdapat beberapa tahap dalam pelaksanaan penelitian. Berikut ini merupakan penjelasan dari setiap tahapnya.

\subsection{Survei/Observasi}

Observasi parkir dilakukan untuk kendaraan parkir off street parking dan on street parking. Observasi parkir dilakukan pada hari libur (Sabtu dan Minggu) selama jam buka objek wisata (08.00 - 17.00 WIB). Data yang diperoleh dari observasi parkir berupa nomor dan waktu keluar-masuk kendaraan parkir di area area parkir. Pencatatan data parkir di area parkir dilakukan dengan menempatkan surveyor di pintu keluar-masuk area parkir.

Analisis aksesibilitas berdasarkan derajat kejenuhan dan kecepatan tempuh. Traffic counting dilakukan pada hari libur (Sabtu dan Minggu) pada saat jam puncak siang (09.00 - 11.30 WIB) dan sore (13.30 - 16.00 WIB) di ruas jalan akses utama Goa Gong, dengan interval waktu 15 menitan. Data yang diperoleh dari traffic counting berupa Jenis dan Jumlah Kendaraan. Pengukuran kondisi jalan dilakukan dengan melakukan pengukuran lebar jalur lalu lintas, lebar jalan, lebar bahu dan ada tidaknya median jalan. Hambatan samping dilakukan dengan pengamatan secara visual dengan mempertimbangkan kondisi lingkungan di sekitar ruas jalan. Kecepatan tempuh diperoleh dengan melakukan survei foating Car.

\subsection{Pengolahan Data}

Pengolahan data lain berupa perhitungan kebutuhan parkir di kawasan Goa Gong, dengan memperhatikan Akumulasi Parkir, Durasi, Pergantian Parkir (Parking Turn Over) Kapasitas Ruang Parkir, Satuan Ruang Parkir (SRP), Dimensi kendaraan standar, dan Indeks Parkir.

Pengolahan data aksesibilitas dilakukan berdasarkan MKJI 1997 untuk Jalan Luar Kota yaitu memperhitungkan derajat kejenuhan sebagai nilai perbandingan volume kendaraan dan kapasitas. Tingkat aksesibilitas juga ditentukan dengan memperhatikan besarnya kecepatan tempuh. 


\section{HASIL DAN PEMBAHASAN}

\subsection{Analisis Parkir}

Jumlah kendaraan yang di parkir di area parkir selama waktu survei (9 jam) dari jam 08.00-17.00 WIB pada hari Sabtu dan hari Minggu, untuk mobil dan bus mengalami fluktuasi setiap waktu. Secara umum akumulasi jumlah kendaraan parkir antara hari Sabtu dan Minggu sangat kondisinya berbeda. Salah satu faktor penyebabnya karena pada hari Sabtu sebagian masyarakat ada yang belum libur dan pada hari Minggu hampir semua masyarakat sudah libur, sehingga kesempatan untuk berwisata pada hari Minggu menjadi lebih besar.

Pada hari Sabtu akumulasi tertinggi untuk bus terjadi pada pukul 10.30-10.45 WIB dengan akumulasi kendaraan sebanyak 19 kendaraan, untuk mobil terjadi pada pukul 12.15-12.30 WIB dengan akumulasi kendaraan sebanyak 15 kendaraan. Pada hari Minggu akumulasi tertinggi untuk bus terjadi pada pukul 10.00-10.15 WIB dengan akumulasi kendaraan sebanyak 53 kendaraan, untuk mobil terjadi pada pukul 12.30-12.45 WIB dengan akumulasi kendaraan sebanyak 23 kendaraan. Adapun Grafik Fluktuasi Akumulasi Kendaraan yang parkir di area parkir dapat dilihat pada Gambar 1. dan Gambar 2

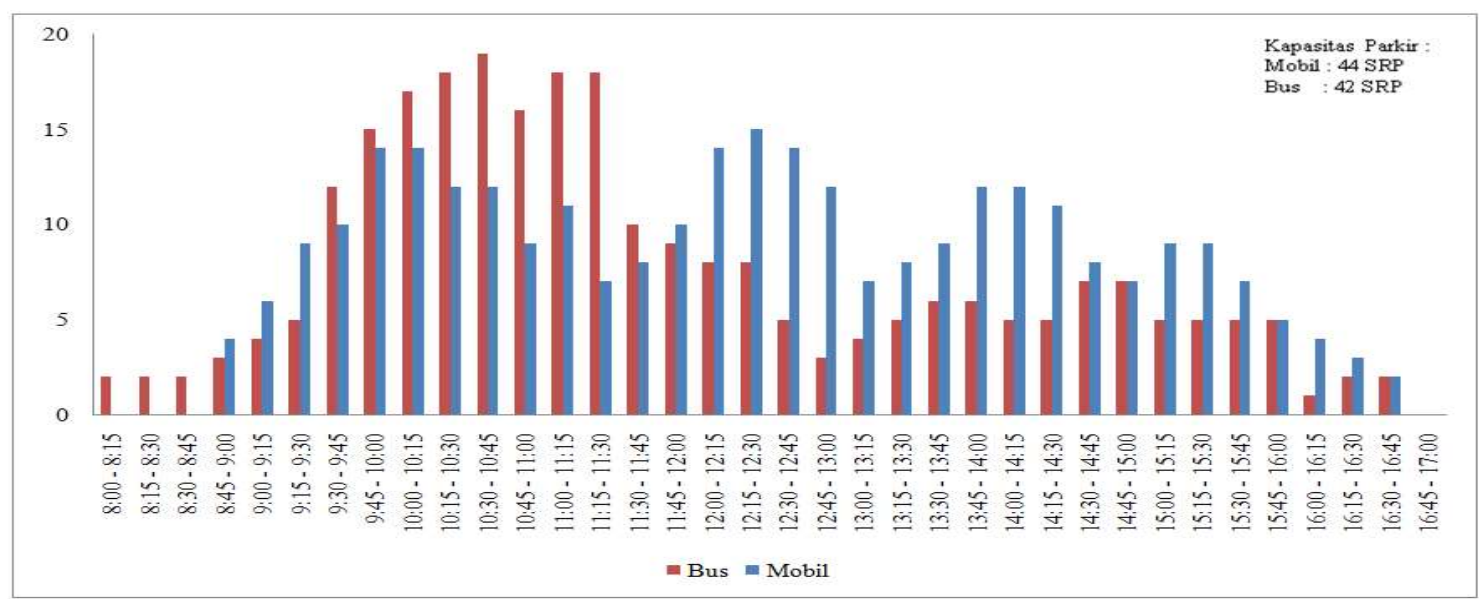

Gambar 1. Grafik Fluktuasi Akumulasi Kendaraan pada Hari Sabtu

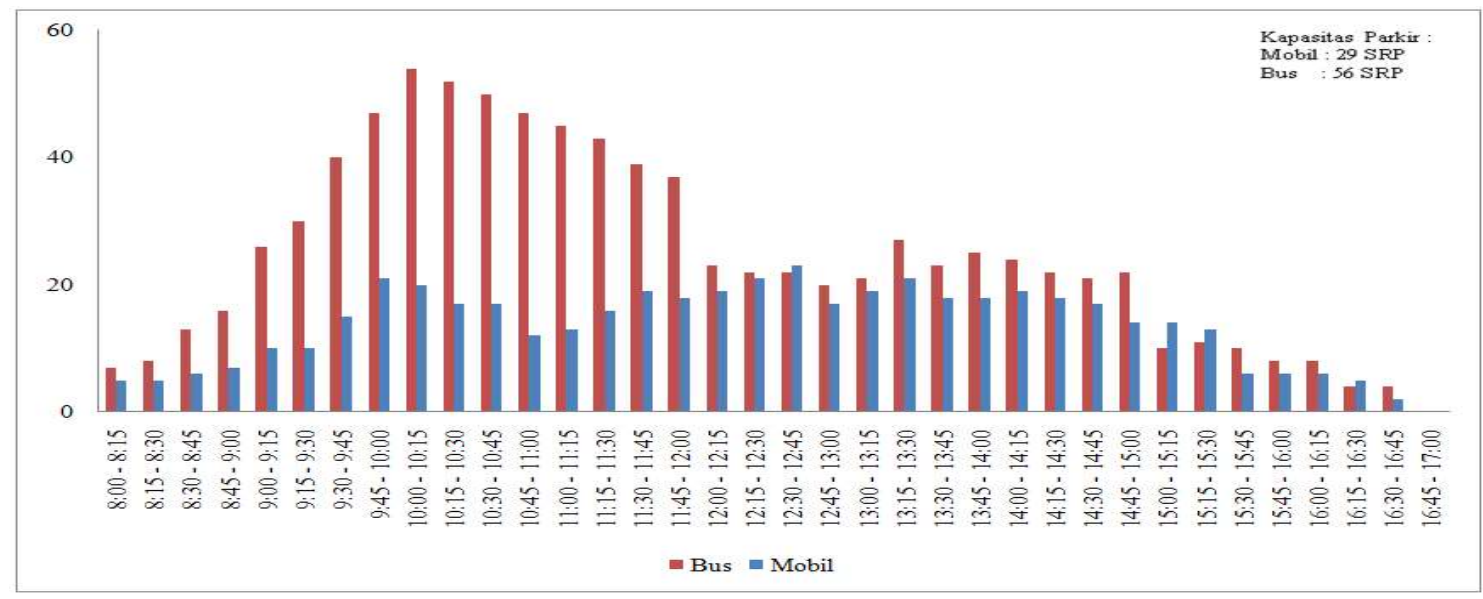

Gambar 2. Grafik Fluktuasi Akumulasi Kendaraan pada Hari Minggu

Tabel 1.Akumulasi Kendaraan Parkir

\begin{tabular}{lcccc}
\hline \multirow{2}{*}{ Akumulasi Parkir } & \multicolumn{3}{c}{ Mobil } & \multicolumn{2}{c}{ Bus } \\
\cline { 2 - 5 } & Sabtu & Minggu & Sabtu & Minggu \\
\hline Total & 294 & 487 & 264 & 881 \\
\hline Maksimum & 15 & 23 & 19 & 54 \\
\hline Minimum & 0 & 0 & 0 & 0 \\
\hline
\end{tabular}




\begin{tabular}{lllll}
\hline Rerata & 8,17 & 13,53 & 7,33 & 24,47 \\
\hline
\end{tabular}

Durasi parkir untuk mobil cenderung lebih kecil daripada durasi parkir untuk bus, karena area parkir untuk mobil dan bus walaupun pada 1 lokasi, tetapi mobil akan lebih mudah menjangkau area parkir dibandingkan dengan bus. Kondisi pintu keluar masuk area parkir yang sempit dan pintu keluar masuk yang menjadi satu, serta adanya belokan dan gradien yang besar menyulitkan kendaraan besar seperti bus untuk menjangkau area parkir.

Tabel 2. Durasi Maksimum, Murasi Minimum dan Durasi Rata-rata

\begin{tabular}{lllll}
\hline \multirow{2}{*}{ Durasi Parkir } & Mobil & & Bus & \\
\cline { 2 - 5 } & Sabtu & Minggu & Sabtu & Minggu \\
\hline Durasi Maximum & $3: 54: 00$ & $4: 04: 00$ & $5: 40: 00$ & $5: 54: 00$ \\
\hline Durasi Minimum & $0: 02: 00$ & $0: 04: 00$ & $0: 09: 00$ & $0: 02: 00$ \\
\hline Durasi Rerata & $1: 24: 20$ & $1: 26: 16$ & $2: 00: 13$ & $1: 53: 55$ \\
\hline
\end{tabular}

Volume kendaraan parkir antara hari Sabtu dan Minggu sangat berbeda. Salah satu faktor yang mempengaruhi adalah jumlah wisatatawan itu sendiri dimana pada hari Sabtu jumlah wisatawan hanya 560 orang sedangkan pada hari Minggu jumlah wisatawan melonjak tajam dengan jumlah 2765 orang. Tabel Volume Parkir, Kapasitas Parkir, Turnover parkir, Indeks Parkir Rerata dan Indeks Parkir Maksimum dapat dilihat pada Tabel 3.

Tabel 3. Volume, Kapasitas, Turnover, Indeks Parkir Rerata dan Indeks Parkir Maksimum

\begin{tabular}{lllll}
\hline \multirow{2}{*}{ Elemen Parkir } & Mobil & \multicolumn{3}{l}{ Bus } \\
\cline { 2 - 5 } & Sabtu & Minggu & Sabtu & Minggu \\
\hline Volume Parkir (kend) & 52 & 84 & 33 & 110 \\
\hline Kapasitas Parkir (SRP) & 44 & 29 & 42 & 56 \\
\hline Turnover Parkir & 1,18 & 2,90 & 0,79 & 1,96 \\
\hline Indeks Parkir Rerata (\%) & 18,56 & 46,65 & 17,46 & 41,52 \\
\hline Indeks Parkir Maksimum (\%) & 34,09 & 79,31 & 45,24 & 94,64 \\
\hline
\end{tabular}

Faktor yang mempengaruhi turnover parkir adalah volume parkir, kapasitas parkir dan durasi parkir. Tingginya volume kendaraan parkir yang tidak diimbangi dengan besarnya kapasitas parkir dapat menyebabkan turnover parkir menjadi lebih tinggi. Perbedaan kapasitas parkir untuk mobil dan bus pada hari Sabtu dan Minggu disebabkan karena pada hari Minggu area parkir diutamakan untuk bus, sedangkan untuk mobil yang tidak dapat tertampung di area parkir akan diarahkan untuk parkir di badan jalan.

Kapasitas parkir yang tidak mencukupi juga akan semakin meningkatkan besarnya indeks parkir. Dimana semakin kecil kapasitas parkir akan menyebabkan indeks parkir yang semakin tinggi yang berarti kinerja parkir yang tidak baik, hal ini dapat diindikasikan dengan banyaknya kendaraan parkir di badan jalan. Tabel 4 menunjukkan jumlah kebutuhan ruang parkir selama waktu pengamatan. Berdasarkan tabel tersebut diketahui bahwa kebutuhan ruang parkir pada hari Minggu lebih tinggi baik untuk parkir bus maupun mobil yang mencapai 13 unit untuk mobil dan 23 unit untuk bus, sedangkan pada hari Sabtu kerbutuhan ruang parkir hanya 8 unit untuk mobil dan 7 unit untuk bus.

Tabel 4. Jumlah Kebutuhan Ruang Parkir

\begin{tabular}{lcccc}
\hline & \multicolumn{2}{c}{ Mobil } & Bus \\
\hline Jumlah kendaraan parkir dalam satu waktu & Sabtu & Minggu & Sabtu & Minggu \\
\hline Rata-rata durasi parkir (jam) & 52 & 84 & 33 & 110 \\
\hline Lama survei (jam) & $1: 24: 20$ & $1: 26: 16$ & $2: 00: 13$ & $1: 53: 55$ \\
\hline Ruang parkir yang dibutuhkan (unit) & 9 & 9 & 9 & 9 \\
\hline
\end{tabular}

Dalam rangka pengembangan Objek Wisata Goa Gong, maka kebutuhan parkir dapat dibandingkan dengan Pedoman Teknis Penyelenggaraan Fasilitas Parkir yang mengacu untuk kegiatan rekreasi. Jika dibandingkan dengan Pedoman Teknis Penyelenggaraan Fasilitas Parkir, Direktorat Jenderal Perhubungan Darat (1996), maka kapasitas ruang parkir yang tersedia sangat jauh dari ketentuan yang disyaratkan, dimana ruang parkir yang 
tersedia hanya sekitar 100 SRP. Jika melihat luas dari Kawasan Objek Wisata yang mencapai 17 Ha (170000 $\mathrm{m}^{2}$ ) untuk zona inti maka seharusnya SRP yang disediakan sekitar 300 SRP. Kebutuhan SRP akan meningkat jika zona penyangga (46 Ha) dan zona pengembangan terbatas $(20 \mathrm{Ha})$ mulai diterapkan.

\subsection{Aksesibilitas}

Dalam penelitian ini data fisik jalan yang digunakan adalah lebar jalan, lebar jalur lalu lintas dan lebar bahu. Berikut ini adalah Tabel 5 tentang data fisik jalan.

Tabel 5. Data Fisik Jalan

\begin{tabular}{cccccccc}
\hline \multicolumn{2}{c}{ Jalan } & \multicolumn{3}{c}{ Bahu } & Jalur Lalu lintas \\
\hline Lebar & Bahan & Pengaman & Lebar & Bahan & Penanganan & Penggunaan & Lebar \\
\hline \multirow{2}{*}{$6 \mathrm{~m}$} & $\begin{array}{l}\text { Lentur } \\
\text { (Baik) }\end{array}$ & $\begin{array}{c}\text { Dinding } \\
\text { Penahan Tanah }\end{array}$ & $1 \mathrm{~m}$ & Campuran & Galian & Parkir & $5 \mathrm{~m}$ \\
\hline
\end{tabular}

\subsubsection{Hambatan Samping}

Hambatan samping di sekitar akses utama Goa Gong termasuk dalam kategori rendah, karena tidak terdapat pusat kegiatan, dimana daerah ini merupakan daerah perdesaan.

\subsubsection{Volume (Q)}

Akses utama Objek Wisata merupakan jalan luar kota dengan kondisi bergunung, dengan jumlah arus yang kurang dari 4500 kendaraan/jam dan lebar jalur lalu lintas yang kurang dari 6 m, maka digunakan Ekuivalen Mobil Penumpang (emp) sebagaimana pada Tabel 6.

Tabel 6. Ekuivalen Mobil Penumpang (emp)

\begin{tabular}{ccccc}
\hline \multicolumn{5}{c}{ ekuivalen mobil penumpang (emp) } \\
\hline MC & LV & MHV & LB & LT \\
\hline 0,9 & 1,0 & 3,0 & 3,2 & 5,5 \\
\hline
\end{tabular}

Berdasarkan hasil survei yang dilakukan pada hari Sabtu dan Minggu di akses utama objek wisata Goa Gong maka diperoleh data sebagaimana pada Tabel 7. dan Tabel 8. Jumlah kendaraan dikonversikan ke dalam satuan mobil penumpang (smp) dengan mengalikan jumlah tiap jenis kendaraan dengan nilai faktor emp masingmasing jenis kendaraan sehingga diperoleh jumlah kendaraan dalam emp.

Jumlah arus lalu lintas yang terjadi antara hari Sabtu dan Minggu sangat berbeda, dimana jumlah arus pada hari Minggu jauh lebih besar dibandingkan arus lalu lintas pada hari Sabtu

Tabel 7. Jumlah Kendaraan pada Hari Sabtu

\begin{tabular}{|c|c|c|c|c|c|c|c|c|c|c|c|}
\hline \multirow{2}{*}{ Waktu } & \multicolumn{5}{|c|}{ Jumlah Kendaraan } & \multicolumn{5}{|c|}{ Jumlah Kendaraan (dalam smp) } & \multirow{2}{*}{ Total } \\
\hline & $\mathrm{MC}$ & LV & MHV & LB & LT & $\mathrm{MC}$ & LV & MHV & LB & LT & \\
\hline $9: 00-9: 15$ & 50 & 17 & 1 & 0 & 2 & 45 & 17 & 3 & 0 & 11 & 76 \\
\hline $9: 15-9: 30$ & 52 & 17 & 1 & 0 & 2 & 47 & 17 & 3 & 0 & 11 & 78 \\
\hline $9: 30-9: 45$ & 34 & 16 & 0 & 0 & 1 & 31 & 16 & 0 & 0 & 6 & 52 \\
\hline $9: 45-10: 00$ & 34 & 21 & 2 & 1 & 0 & 31 & 21 & 6 & 3 & 0 & 61 \\
\hline $10: 00-10: 15$ & 48 & 25 & 0 & 1 & 1 & 43 & 25 & 0 & 3 & 6 & 77 \\
\hline $10: 15-10: 30$ & 50 & 20 & 1 & 1 & 0 & 45 & 20 & 3 & 3 & 0 & 71 \\
\hline $10: 30-10: 45$ & 41 & 18 & 4 & 1 & 1 & 37 & 18 & 12 & 3 & 6 & 76 \\
\hline $10: 45-11: 00$ & 49 & 12 & 4 & 0 & 0 & 44 & 12 & 12 & 0 & 0 & 68 \\
\hline $11: 00-11: 15$ & 30 & 14 & 3 & 1 & 0 & 27 & 14 & 9 & 3 & 0 & 53 \\
\hline $11: 15-11: 30$ & 40 & 16 & 0 & 0 & 1 & 36 & 16 & 0 & 0 & 6 & 58 \\
\hline $13: 30-13: 45$ & 38 & 17 & 3 & 0 & 0 & 34 & 17 & 9 & 0 & 0 & 60 \\
\hline $13: 45-14: 00$ & 37 & 4 & 5 & 0 & 0 & 33 & 4 & 15 & 0 & 0 & 52 \\
\hline $14: 00-14: 15$ & 27 & 16 & 3 & 1 & 0 & 24 & 16 & 9 & 3 & 0 & 53 \\
\hline $14: 15-14: 30$ & 40 & 14 & 3 & 0 & 0 & 36 & 14 & 9 & 0 & 0 & 59 \\
\hline $14: 30-14: 45$ & 23 & 22 & 4 & 2 & 0 & 21 & 22 & 12 & 6 & 0 & 61 \\
\hline
\end{tabular}




\begin{tabular}{cccccccccccc}
$14: 45-15: 00$ & 28 & 18 & 0 & 2 & 0 & 25 & 18 & 0 & 6 & 0 & 50 \\
\hline $15: 00-15: 15$ & 34 & 16 & 1 & 1 & 2 & 31 & 16 & 3 & 3 & 11 & 64 \\
\hline $15: 15-15: 30$ & 38 & 10 & 0 & 0 & 0 & 34 & 10 & 0 & 0 & 0 & 44 \\
\hline $15: 30-15: 45$ & 45 & 9 & 0 & 0 & 0 & 41 & 9 & 0 & 0 & 0 & 50 \\
\hline $15: 45-16: 00$ & 60 & 18 & 0 & 0 & 3 & 54 & 18 & 0 & 0 & 17 & 89 \\
\hline Jumlah & $\mathbf{7 9 8}$ & $\mathbf{3 2 0}$ & $\mathbf{3 5}$ & $\mathbf{1 1}$ & $\mathbf{1 3}$ & $\mathbf{7 1 8}$ & $\mathbf{3 2 0}$ & $\mathbf{1 0 5}$ & $\mathbf{3 5}$ & $\mathbf{7 2}$ & $\mathbf{1 2 5 0}$ \\
\hline Rata-rata & $\mathbf{1 6 0}$ & $\mathbf{6 4}$ & $\mathbf{7}$ & $\mathbf{2}$ & $\mathbf{3}$ & $\mathbf{1 4 4}$ & $\mathbf{6 4}$ & $\mathbf{2 1}$ & $\mathbf{7}$ & $\mathbf{1 4}$ & $\mathbf{2 5 0}$ \\
\hline
\end{tabular}

Tabel 8. Jumlah Kendaraan pada Hari Minggu

\begin{tabular}{|c|c|c|c|c|c|c|c|c|c|c|c|}
\hline \multirow{2}{*}{ Waktu } & \multicolumn{5}{|c|}{ Jumlah Kendaraan } & \multicolumn{5}{|c|}{ Jumlah Kendaraan (dalam smp) } & \multirow{2}{*}{ Total } \\
\hline & $\mathrm{MC}$ & LV & MHV & LB & LT & $\mathrm{MC}$ & LV & MHV & LB & LT & \\
\hline 9:00 - 9:15 & 23 & 31 & 6 & 3 & 0 & 21 & 31 & 18 & 10 & 0 & 79 \\
\hline $9: 15-9: 30$ & 27 & 32 & 1 & 2 & 0 & 24 & 32 & 3 & 6 & 0 & 66 \\
\hline $9: 30-9: 45$ & 23 & 39 & 2 & 1 & 0 & 21 & 39 & 6 & 3 & 0 & 69 \\
\hline $9: 45-10: 00$ & 49 & 27 & 2 & 5 & 0 & 44 & 27 & 6 & 16 & 0 & 93 \\
\hline $10: 00-10: 15$ & 65 & 27 & 1 & 3 & 0 & 59 & 27 & 3 & 10 & 0 & 98 \\
\hline $10: 15-10: 30$ & 122 & 40 & 2 & 2 & 0 & 110 & 40 & 6 & 6 & 0 & 162 \\
\hline $10: 30-10: 45$ & 83 & 33 & 2 & 5 & 0 & 75 & 33 & 6 & 16 & 0 & 130 \\
\hline $10: 45-11: 00$ & 167 & 32 & 1 & 0 & 0 & 150 & 32 & 3 & 0 & 0 & 185 \\
\hline $11: 00-11: 15$ & 83 & 56 & 3 & 2 & 4 & 75 & 56 & 9 & 6 & 22 & 168 \\
\hline $11: 15-11: 30$ & 39 & 34 & 1 & 3 & 0 & 35 & 34 & 3 & 10 & 0 & 82 \\
\hline $13: 30-13: 45$ & 39 & 30 & 1 & 4 & 0 & 35 & 30 & 3 & 13 & 0 & 81 \\
\hline $13: 45-14: 00$ & 31 & 34 & 0 & 0 & 1 & 28 & 34 & 0 & 0 & 6 & 67 \\
\hline $14: 00-14: 15$ & 37 & 20 & 1 & 0 & 0 & 33 & 20 & 3 & 0 & 0 & 56 \\
\hline $14: 15-14: 30$ & 34 & 23 & 0 & 0 & 3 & 31 & 23 & 0 & 0 & 17 & 70 \\
\hline $14: 30-14: 45$ & 32 & 23 & 1 & 1 & 1 & 29 & 23 & 3 & 3 & 6 & 64 \\
\hline $14: 45-15: 00$ & 35 & 22 & 1 & 0 & 0 & 32 & 22 & 3 & 0 & 0 & 57 \\
\hline $15: 00-15: 15$ & 35 & 27 & 5 & 1 & 1 & 32 & 27 & 15 & 3 & 6 & 82 \\
\hline $15: 15-15: 30$ & 58 & 26 & 1 & 1 & 0 & 52 & 26 & 3 & 3 & 0 & 84 \\
\hline $15: 30-15: 45$ & 41 & 23 & 0 & 0 & 0 & 37 & 23 & 0 & 0 & 0 & 60 \\
\hline $15: 45-16: 00$ & 35 & 26 & 0 & 0 & 1 & 32 & 26 & 0 & 0 & 6 & 63 \\
\hline Jumlah & 1058 & 605 & 31 & 33 & 11 & 952 & 605 & 93 & 106 & 61 & 1816 \\
\hline Rata-rata & 212 & 121 & 6 & 7 & 2 & 190 & 121 & 19 & 21 & 12 & 363 \\
\hline
\end{tabular}

\subsubsection{Kapasitas Jalan}

Kondisi jalan akses utama Goa Gong merupakan jalan luar kota yang berada di pegunungan dan tidak memiliki median, dengan 2 lajur 2 arah, sehingga digunakan kapasitas dasar (Co) sebesar 2900. Lebar efektif jalan sebesar 5,5 m sehingga digunakan faktor penyesuaian lebar jalan (FCw) sebesar 0,69, seadangkan karena jalan ini merupakan jalan 2 lajur 2 arah tak terbagi, dengan pembagian lalu lintas yang seimbang, masing-masing 50\% - 50\% untuk tiap lajur tiap arah, maka faktor penyesuaian pemisahan arah (FCsp) sebesar 1, dan faktor penyesuaian hambatan samping (FCsf) digunakan nilai sebesar 0,95 karena memiliki hambatan samping dengan kategori rendah dengan lebar bahu $1 \mathrm{~m}$. Adapun tabel penentuan nilai kapasitas jalan dapat dilihat pada Tabel 9.

Tabel 9. Tabel Perhitungan Kapasitas Jalan

\begin{tabular}{ccccc}
\hline Co & FCw & FCsp & FCsf & C \\
\hline 2900 & 0,69 & 1 & 0,95 & 1901 \\
\hline
\end{tabular}

\subsubsection{Derajat Kejenuhan}

Derajat kejenuhan yang terjadi pada hari Sabtu cenderung lebih rendah dibandingkan dengan derajat kejenuhan pada hari Minggu, karena jumlah arus lalu lintas pada hari Minggu lebih besar daripada jumlah arus lalu lintas pada hari Sabtu. Berikut ini adalah Tabel 10 tentang derajat kejenuhan.

Tabel 10. Penentuan Derajat Kejenuhan 


\begin{tabular}{cccc}
\hline Hari & Kapasitas & Arus Lalu lintas & Derajat Kejenuhan \\
\hline Sabtu & 1901 & 250 & 0,13 \\
\hline Minggu & 1901 & 363 & 0,19 \\
\hline
\end{tabular}

Tingkat pelayanan atau "Level of Service" adalah tingkat pelayanan dari suatu jalan yang menggambarkan kualitas suatu jalan. Berdasarkan besarnya nilai derajat kejenuhan dan besarnya kecepatan maka tingkat pelayanan jalan eksisting di objek wisata Goa Gong termasuk dalam kategori A, dengan besarnya derajat kejenuhan sebesar 0,13 pada hari Sabtu, sedangkan besarnya derajat kejenuhan sebesar 0,14 pada hari Minggu.

Data hasil perhitungan tingkat pelayanan jalan prediksi untuk 5 tahun yang akan datang (tahun 2022) berdasarkan perhitungan pertumbuhan lalu lintas (untuk prediksi volume lalu lintas). Tingkat pertumbuhan volume lalu lintas mengacu pada pertumbuhan jumlah pengunjung yaitu sebesar $19,96 \%$ per tahun, sehingga diperoleh nilai prediksi seperti pada Tabel 11.

Berdasarkan hasil prediksi untuk waktu 5 tahun, maka tingkat pelayanan jalan di akses utama Goa Gong mengalami penurunan dimana sebelumnya berada pada kategori A menjadi kategori B pada hari Sabtu dan kategori $\mathrm{C}$ pada hari Minggu. Jika hal ini tidak dilakukan penanganan, maka ke depannya tingkat layanan jalan akan semakin turun seiring dengan bertambahnya jumlah wisatawan yang semakin meningkat, apalagi akses ini merupakan akses utama menuju objek wisata lain juga, sedangkan Kabupaten Pacitan sedang gencar-gencarnya dalam sektor pariwisata.

Tabel 11. Prediksi Tingkat Pelayanan Jalan Tahun 2022

\begin{tabular}{cccccccc}
\hline \multirow{2}{*}{ Hari } & \multirow{2}{*}{$\begin{array}{c}\text { Kapasitas } \\
\text { Jalan }\end{array}$} & \multicolumn{2}{c}{ Arus } & \multicolumn{2}{c}{ Derajat Kejenuhan } & \multicolumn{2}{c}{ Tingkat Pelayanan } \\
\cline { 3 - 8 } & & 2017 & 2022 & 2017 & 2022 & 2017 & 2022 \\
\hline Sabtu & 1901 & 250 & 621 & 0,13 & 0,33 & A & B \\
\hline Minggu & 1901 & 363 & 910 & 0,19 & 0,48 & A & C \\
\hline
\end{tabular}

\subsubsection{Kecepatan}

Data kecepatan dapat dilihat pada Tabel 12. Kecepatan tempuh kendaraan pada hari Sabtu lebih besar dibandingkan kecepatan tempuh pada hari Minggu, hal ini selain terjadi karena tingginya arus lalu lintas, juga karena adanya parkir di badan jalan yang lebih banyak terjadi pada hari Minggu dibandingkan pada hari Sabtu. Berdasarkan Tabel 12, diketahui bahwa kecepatan rata-rata kendaraan 38,86 km/jam pada hari Sabtu, sedangkan pada hari Minggu kecepatan rata-rata kendaraan sebesar 35,02 km/jam. Besarnya kecepatan masih memenuhi kecepatan rencana untuk jalan kolektor luar kota yang berada di daerah pegunungan dengan kecepatan rencana sebesar 30 - 50 km/jam sesuai dengan Tata Cara Perencanaan Geometrik Jalan Antar Kota (1997).

Tabel 12. Kecepatan Tempuh Mencapai Objek Wisata Goa Gong

\begin{tabular}{|c|c|c|c|c|c|c|c|}
\hline \multirow[t]{2}{*}{ Sabtu } & \multicolumn{2}{|c|}{ Waktu Tempuh S - U } & \multicolumn{2}{|c|}{ Waktu Tempuh U - S } & \multirow[t]{2}{*}{ Jarak (m) } & \multicolumn{2}{|c|}{ Kecepatan $(\mathrm{km} / \mathrm{jam})$} \\
\hline & detik & jam & detik & jam & & S-U & U-S \\
\hline \multirow[t]{4}{*}{09.00 - selesai } & 691 & 0,19 & 688 & 0,19 & 6,7 & 34,91 & 35,06 \\
\hline & 629 & 0,17 & 617 & 0,17 & 6,7 & 38,35 & 39,09 \\
\hline & 604 & 0,17 & 643 & 0,18 & 6,7 & 39,93 & 37,51 \\
\hline & & & & & & 37,73 & 37,22 \\
\hline \multirow[t]{4}{*}{15.00 - selesai } & 598 & 0,17 & 594 & 0,17 & 6,7 & 40,33 & 40,61 \\
\hline & 607 & 0,17 & 596 & 0,17 & 6,7 & 39,74 & 40,47 \\
\hline & 601 & 0,17 & 601 & 0,17 & 6,7 & 40,13 & 40,13 \\
\hline & & & & & & 40,07 & 40,40 \\
\hline \multicolumn{8}{|l|}{ Minggu } \\
\hline \multirow[t]{4}{*}{09.00 - selesai } & 706 & 0,20 & 651 & 0,18 & 6,7 & 34,16 & 37,05 \\
\hline & 647 & 0,18 & 839 & 0,23 & 6,7 & 37,28 & 28,75 \\
\hline & 679 & 0,19 & 755 & 0,21 & 6,7 & 35,52 & 31,95 \\
\hline & & & & & & 35,66 & 32,58 \\
\hline \multirow[t]{4}{*}{15.00 - selesai } & 815 & 0,23 & 650 & 0,18 & 6,7 & 29,60 & 37,11 \\
\hline & 702 & 0,20 & 620 & 0,17 & 6,7 & 34,36 & 38,90 \\
\hline & 679 & 0,19 & 603 & 0,17 & 6,7 & 35,52 & 40,00 \\
\hline & & & & & & 33,16 & 38,67 \\
\hline
\end{tabular}




\subsection{Alternatif Penanganan Masalah}

Keterbatasan penyediaan tempat parkir, memaksa badan jalan dijadikan sebagai tempat parkir, sehingga berpotensi terjadi kemacetan lalu lintas. Kemacetan dapat menurunkan tingkat keamanan dan kenyamanan bagi pengguna jalan, menurunkan kecepatan perjalanan, menambah waktu perjalanan dan naiknya biaya operasi kendaraan. Sebelum timbul permasalah yang lebih kompleks, maka harus segera dilakukan penanganan.

Prioritas penanganan masalah adalah dengan penambahan kapasitas ruang parkir termasuk fasilitas pendukung lainnya disertai dengan manajemen parkir melalui pembatasan durasi parkir dan tarif parkir. Pembatasan durasi parkir dan tarif parkir akan dapat meningkatkan tingkat turnover sehingga penggunaan ruang parkir semakin efektif. Alternatif lain yang dapat dilakukan dengan pelebaran jalan, penyediaan angkutan umum wisata dan pembuatan regulasi terkait serta penegakan hukum secara tegas.

\section{KESIMPULAN}

Indeks parkir secara umum tidak terlalu tinggi tetapi pada jam-jam tertentu indeks parkir mencapai lebih dari 70 $\%$, bahkan mendekati $100 \%$. Untuk perencanaan seharusnya disediakan 300 SRP karena luas kawasan objek wisata yang mencapai $17 \mathrm{Ha}\left(170000 \mathrm{~m}^{2}\right)$.

Berdasarkan nilai derajat kejenuhan, tingkat layanan jalan di akses utama Objek Wisata Goa Gong termasuk dalam kategori A, dengan derajat kejenuhan sebesar 0,13 pada hari Sabtu dan 0,19 pada hari Minggu. Prediksi tingkat pelayanan jalan pada tahun 2022 turun ke dalam kategori B pada hari Sabtu dengan derajat kehenuhan 0,33 dan kategori $\mathrm{C}$ pada hari Minggu dengan derajat kejenuhan sebesar 0,48.

Kecepatan rata-rata 38,86 km/jam pada hari Sabtu dan 35,02 km/jam pada hari Minggu. Besarnya kecepatan masih memenuhi kecepatan rencana untuk jalan kolektor luar kota di daerah pegunungan dengan kecepatan rencana sebesar 30 - 50 km/jam sesuai dengan Tata Cara Perencanaan Geometrik Jalan Antar Kota (1997).

Prioritas penanganan masalah adalah dengan penambahan kapasitas ruang parkir termasuk fasilitas pendukung lainnya disertai dengan manajemen parkir. Alternatif lain yang dapat dilakukan dengan pelebaran jalan, penyediaan angkutan umum wisata dan pembuatan regulasi terkait serta penegakan hukum secara tegas.

\section{DAFTAR PUSTAKA}

Asih, Meita Bustanul dan Imam Muthohar, 2012, Upaya Pemecahan Masalah Lalu Lintas Akibat Aktivitas Sisi Jalan Yang Tinggi Dengan Analisis Tundaan (Studi Kasus : Jalan Kesehatan, Yogyakarta), The $15^{\text {th }}$ FSTPT International Symposium, STTD Bekasi

Ciptaningrum, Mega Satya, dkk, 2016, Analisis Kinerja Jalan Kota Malang menggunakan Metode FCD (Floating Car Data), JNTETI, Vol. 5, No. 1, Februari 2016

Direktorat Jenderal Bina Marga, 1997, Manual Kapasitas Jalan Indonesia (MKJI), PT. Bina Karya

Direktorat Jenderal Bina Marga, 1997, Tata Cara Perencanaan Jalan Antar Kota

Keputusan Direktur Jenderal Perhubungan Darat, Tahun 1996, Nomor : 272/HK.105/DRJD/96 tentang Pedoman Teknis Penyelenggaraan Fasilitas Parkir

Moeis, Herman dan Ali Fahmi, 2012, Model Layanan Transportasi Untuk Menarik Minat Wisatawan Berkunjung Ke Objek Wisata Di Jawa Timur, Governance Jurnal Kebijakan dan Manajemen Publik, Vol.3, No.1, April 2012: 24-34

Munawar, Ahmad, 2004, Manajemen Lalu lintas Perkotaan, Beta Offset, Yogyakarta, Indonesia

Nabal, Alfred Rodriques Januar, 2014, Evaluasi Kebutuhan Lahan Parkir Pada Area Parkiran Kampus Fisip Universitas Atma Jaya Yogyakarta, Jurnal Teknik Sipil, Vol. 13, No. 1, Hal. 32-44, Oktober 2014

Ningsih, Dewi Handayani Untari, 2010, Analisia Optimasi Jaringan Jalan Berdasar Kepadatan Lalulintas di Wilayah Semarang dengan Berbantuan Sistem Informasi Geografi (Studi Kasus Wilayah Dati II Semarang), Jurnal Teknologi Informasi Dinamik Vol. XV, No.2, hal. : 121-135

Rahmawati, Alfiani, 2016, Korespondensi antara Faktor Penyebab Kemacetan dan Solusinya, Prosiding Temu Ilmiah IPLBI 2016, Hal. B 043-048, 30 November 2016

Savenny, Pratiwi dkk, 2017, Persepsi Wisatawan Dalam Pemanfaatan Badan Jalan Sebagai Lahan Parkir Bagi Pengunjung Di Objek Wisata Kota Bukittinggi, Diakses tanggal 2 Oktober 2017, melalui http://jim.stkip-pgri-sumbar.ac.id/jurnal/view/zjV

Supriatna, Nandan, 2008, Kajian Proses Manuver Parkir di Badan Jalan di Kota Bandung, Jurnal Sipil Kokoh, Vol. 6, No. 1, Januari 2008

Tambunan, Nani, 2009, Peranan Transportasi Dalam Priwisata, Majalah Ilmiah Panorama Nusantara, Edisi VI, Januari - Juni 2009 